\title{
Effect of Grafting Eggplant (Solanum melongena L.) on its Selected Useful Characters
}

\author{
Marian BOGOESCU ${ }^{1}$, Madalina DOLTU ${ }^{1}$ \\ ${ }^{1}$ Research and Development Institute for Industrialization and Marketing of Horticultural Products, \\ Intrarea Binelui,no.1A,sector 4,Bucuresti,042159 \\ *)Corresponding author, e-mail: bogoescumarian@gmail.com
}

BulletinUASVM Horticulture 72(2) / 2015

Print ISSN 1843-5254, Electronic ISSN 1843-5394

DOI:10.15835/buasvmcn-hort:11349

\begin{abstract}
The grafting eggplants cultivars onto rootstocks that are resistant to the soil-borne pathogens and nematodes is a method known for many years, but which has improved and spread quickly in the last years. The objective of these experiments was to evaluate the influence of some rootstocks on the crop of grafted eggplant. The Romanian eggplant "Andra F1" and Dutch hybrid "Sharapova", were grafted onto the rootstocks "King Kong, Emperador, Hikyaku, KA-312, Torvum vigor and Espina". It was determined the influence of the eggplants rootstock on the marketable yield, early harvest, fruits quality and nutritional value. There were calculated the disease incidence (I $\%$ ), disease severity (S \%) and attack degree (AD\%) at the experimental variants for soil pathogens Verticillium dahliae, respectively Fusarium oxysporum f. sp. melongenae and nematodes Meloidogyne spp. The resulted values were used to calculate the attack degree (as an expression of extending attack seriousness) on the following formula: $\mathrm{AD} \%=(\mathrm{S} \% \mathrm{x} \mathrm{I} \%) / 100$, where $\mathrm{AD} \%$ represents attack degree. Presence of root galls induced by nematodes, were visually assessed at the end of the trials on $50 \%$ of the plants harvested from the middle of the plots. The rootstocks which led to the increase of yield and tolerance to the lower soil temperatures as well as to a earliness character of the yield were "Emperador, King Kong and Hikyaku". The percent of first class fruits were higher to the grafted eggplants than to the non-grafted plants. It not were registered significant differences between rootstocks concerning the influence of rootstock on the nutritional value of the eggplants fruits. The frequency of damage to the plants of eggplants by the soil-born pathogen and nematodes attack was significantly reduced by grafting eggplant scions onto resistant rootstocks. The rootstocks "Emperador, King Kong and Hikyaku" led to increased marketable yield, fruits quality, early harvest and nutritional value. "Emperador F1" rootstocks reduced the frequency and severity of infection with the soil-borne pathogens and the nematodes attack.
\end{abstract}

Keywords: nematodes, quality, rootstock, scion, soil-borne pathogens.

\section{INTRODUCTION}

The biotic and abiotic environmental factors offer optimum breeding conditions for numerous species of pathogenic agents causing great production damage; Fusarium oxysporum f.sp. melongenae, Verticillium dahliae and nematodes are very destructive in eggplants crops and one of the most limiting factors to farmer's income (Bletsos et al., 2003). Since crop rotation is rarely adopted, the reduction of yield, both in quantity and quality, progressively affects the crops, thus making necessary the adoption of soil disinfestations practices or other methods
(Gullino et al., 2003). Soil-borne pathogens such as Verticillium dahliae and Fusarium oxysporum f.sp. melongenae may cause yield losses that exceed $60 \%$ in affected production areas (Bletsos et al., 2003).

Growing vegetables without soil fumigants has remained a challenge, in part because commercially acceptable eggplant cultivars produced through conventional breeding lack resistance to many soil borne plant pathogens(Bausher and Chellemi, 2010).

One possible method to reduce production losses is the use of grafted plants. Productive 
eggplant cultivars grafted onto rootstocks that are resistant to soil pests and diseases, were achieved some time ago and have spread quickly. It is extremely important during the grafting process to ensure the vascular fusion between the scion and rootstock by using a cut that maximizes the contact surface and creating the proper conditions for close contact between those two plants (Assenza, 2004). Joining a suitable cultivar scion to a wildtype rootstock which has a robust root system and strong resistance to soil pests and diseases induce the tolerance features to less favourable conditions of soil and environment (Edelstein and Ben-Hur, 2015; Oda,1993).The main result of the grafting process is the increase of the resistance against soil diseases such as Fusarium, Verticillium or nematodes (Bogoescu, 2007).

The objective of the researches was to evaluate the performance of the eggplants grafting on some rootstocks, in greenhouse conditions, in Romania.

\section{MATERIALS AND METHODS}

The reserach was done in the pilot greenhouse of the Horting Institute. The Romanian eggplant hybrid "Andra F1" and Holland hybrid "Sharapova F1", used as scions, were grafted onto the rootstocks "King Kong", "Emperador", "Hikyaku", "KA-312", "Torvum vigor" and "Espina".

The main features of the used rootstocks are:

King Kong is a rootstock developed by Rijk Zvaan, Netherlands. It has a high production potential. It leads to a very good balance of culture, leading to a good fruiting and quality. It is a rootstock that does not negatively affect early maturation. It induces graft tolerance to low temperatures. It shows resistance or tolerance to Fusarium oxysporum var. lycopersici race, 0.1, Verticillium albo-atrum, Verticillium dahliae and Meloidogine ingognita.

Emperador F1 belongs to hybrid rootstocks resistant category KVF (Pyrenochaeta lycopersici, Dydimella lycopersici, Verticilium spp. și Fusarium spp.), resulted from crossing between Lycopersicon esculentum and $L$. hirsutum produced by Rijk Zwaan, Netherlands. It is a generative rootstock, very vigorous which conducts to obtaining big fruits and increasing production. It has a good tolerance to low temperatures. It is compatible with lots of cultivars of tomatoes and eggplant. It shows a high level of resistance to nematodes.
Hikyaku F1(Solanum melongela) is a rootstock for grafting eggplants created by Kaneko Seeds Co., Japan, which has resistance to: Fusarium oxysporum var. lycopersici race, 0.1, Fusarium oxysporum lycopersici race radicis - 0.1, Verticillium albo-atrum, Verticillium dahliae, Meloidogine ingognita. This rootstock is recommended to be used especially in fields infested with vascular disease; it confers rusticity and force to the graft; it has a vigorous growth even under low temperatures conditions, being recommended for cooler areas or to be planted in early spring.

KA-312 is an rootstock for eggplants created by Kaneko Seeds Co.Japan, which is resistant to Fusarium oxysporum var. lycopersici race, 0.1, Verticillium albo-atrum, Verticillium dahliae, Meloidogine ingognita. It does not affect the organoleptic qualities of the fruit.

Torvum vigor derives from Solanum torvum and it is produced by Kaneko Seeds Co., Japan; it is a very vigorous cultivar which can be used only as rootstock for eggplants; it shows resistance to Pseudomonas solanacearum, Verticillium spp., Fusarium spp. and nematodes. It can be cultivated and gives good results in prolonged cycle eggplants culture and confers resistance to high temperatures.

Espina is a special selection of Solanum torvum with high resilience and force, designated for eggplants grafting. It has good tolerance to weather cooling; therefore its root shave high absorption efficiency even at low temperatures. The harvest is consistently high throughout all harvesting period. It does not affect the organoleptic qualities of the fruit. It determine significant increases in production. It has a high resistance to Fusarium oxysporum f.sp melongenae and middle resistance to Meloidogine incognita,Pseudomonas solanacearum, Pyrenochaeta lycopersici.

The main features of the two cultivars we used are the following:

Andra F1: semi early hybrid, obtained at the Research and Development Institute for Vegetables and Flowers Vidra, recommended for growing in the field and under covers. The plants are high; the bushes there are tight and semi lax. The fruits are ovoid, elongated, of 300 grams on average of dark purple color, with a length of 19$22 \mathrm{~cm}$ and $6-7 \mathrm{~cm}$ diameter. They have a potential of $45-50$ t/ha from which over $85 \%$ of first quality. 
It has tolerance to Verticillium dahliae, and it is Phytophthora resistant.

Sharapova F1 is an early and vigorous hybrid product by Rijk Zwaan, for protected and field cultures, which has shiny dark black and uniform fruits, with dense white pulp, with pleasant taste, no spikes, cylindrical-oval, weighting 350-400grams, high production potential, resistant to thermal stress, and with resistance to phytopathogens.

The researches refer to the behavior of (rootstock $\mathrm{x}$ scion) combinations in terms of average production recorded, earliness grade (average yield per plant, harvested in the first 30 days of harvest), commercial quality and nutritional value of eggplant fruit.

Experimental variants were organized in randomized blocks each consisting of three repetitions. Each of the three areas of one variant was of $10 \mathrm{~m}^{2}$; resulting a total area of $4320 \mathrm{~m}^{2}$.The eggplants were planted on May 03 ${ }^{\text {rd }}, 2014$ and cleared on October $27^{\text {th }}, 2014$.

Comparative analysis of (rootstock x scion) combinations has been performed using a culture of non-grafted eggplants with a density of 24000 plants/ha and one of grafted eggplants with a density of 20000 plants /ha.

Observations on the phytosanitary status were made under natural infection conditions. Soil samples were taken to determine the load with soil pathogens and nematodes. Isolation of fungi in culture substrate was made by the method of successive dilutions. Two culture selective mediums were used for growth: Martin and Waksman, to avoid bacterial growth. Weekly observations were made on the emergence and evolution of pathogens and pests. Data obtained from combinations graft/rootstock were compared with data registered in non-grafted plants (control variant).

For identified pathogens there were calculated the disease incidence (I \%), disease severity (S $\%)$ and attack degree (AD\%) in the experimental variants.

$\mathrm{I} \%$ (disease incidence $)=\mathrm{N} \times 100 / \mathrm{Nt}$, where: $\mathrm{N}=$ number of attacked plants and $\mathrm{Nt}=$ total plants analyzed; $\mathrm{S} \%$ (disease severity) $=\sum \mathrm{x}$ (I $\mathrm{x} \mathrm{f}) / \mathrm{n}$, where: $\mathrm{i}=\%$ index; $\mathrm{f}=$ number of plants with an index; $\mathrm{n}=$ total number of attacked plants analyzed; $\mathrm{AD} \%$ (attack degree $)=(\mathrm{S} \% \mathrm{x}$ I \%) $/ 100$.

Observations on identifying nematodes and plant roots galls on demonstration plots were carried out when clearing eggplants culture according to the method described by Di Vito and Lamberti (1971), in scoring scale (0-5):

$0=$ no galls;

1 = slight infection, presence of 1-5 galls located only on few roots;

2 = slight infection, widespread galls, presence of no more than 20 galls well spread on root system;

$3=$ infection with widespread galls, more than 20

galls evident and well spread on root system;

4 = strong infection, root system cut down and deformed due to the presence of big galls on the main roots;

5 = very strong infection, root system cut down and totally deformed due to the presence of big galls, absence capillary roots.

Determination of nematode species from genus Meloidogyne was made directly by placing nematodes in microscopic samples. Nematodes were collected by the extraction method.

Concluding observations were done in the fourth decade of October, during the clearing of experimental plots. Statistical analysis was performed by Duncan's test.

\section{RESULTS AND DISCUSSION}

Analysis of the results obtained (Tab.1) refers to the influence of grafting eggplants on average productions, the degree of earliness (amount harvest in the first 30days) and the sum of degrees of temperature at first harvest, depending on the soil temperature at $10-15 \mathrm{~cm}$ depth, when plants were seed; the soil temperature when planting eggplants should not be less than $17^{\circ} \mathrm{C}$. Regarding this aspect, eggplants planting was done at two moments, respectively 12 and $17^{\circ} \mathrm{C}$, at a depth of $10-15 \mathrm{~cm}$ in soil.

The mean yield of grafted eggplant fruits has been $122.4 \mathrm{t} /$ ha while at the non-grafted eggplants was registered only an yield of $98.8 \mathrm{t} / \mathrm{ha}$. Regarding the (rootstock $\mathrm{x}$ scion) combinations, the best results were recorded for grafting (Emperador x Sharapova), where there was an average production per plant of $7.77 \mathrm{~kg}$, respectively (Hikyaku x Sharapova) where there was an average production per plant of $7.32 \mathrm{~kg}$.

Rootstocks that have led to high productions were Emperador (an average of $7.04 \mathrm{~kg} /$ plant), King Kong and K-312(an average of 5.81kg/plant). Tolerance to low soil temperatures was given by 
the rootstocks Emperador (an average of $5.64 \mathrm{~kg} /$ plant), followed by King Kong and Hikyaku with 4.65 and respectively $4.51 \mathrm{~kg} / \mathrm{plant}$.

A higher degree of earliness was recorded in combinations between (Sharapova $\mathrm{x}$ Emperador) with an average of $2.44 \mathrm{~kg}$ per plant harvested in the first 30 days of harvest and (Hikyaku $x$ Sharapova) with an average of $1.67 \mathrm{~kg}$ per plant.

The rootstock that showed earliness features were Emperador (an average of $1.97 \mathrm{~kg}$ per plant harvested), Hikyaku (1.62kg /plant) and King Kong (1.31kg /plant).

The above results in general agree with other research who found that yield and qualitative characteristics of the eggplants fruits were not affected by grafting process, on the
contrary(Bletsos et al.,2003; Khah, 2011; Romano and Paratore, 2001).

The warm requirements, expressed as the sum of degrees of temperature until the first harvest, was between $3333^{\circ} \mathrm{C}$ (Espina) and $3621^{\circ} \mathrm{C}(\mathrm{KA}-312)$ versus average of non-grafted eggplants which was less high, respective $3323^{\circ} \mathrm{C}$. A slight tardiness was confirmed, the additional amount of the sum of degrees of temperature for grafted plants ranging between 48 and $188^{\circ} \mathrm{C}$ due to grafting, representing 2 to 8 days, depending on the rootstock, scion and environmental conditions.

Grafting eggplants led to improving their quality (Tab.2). Fruits quality was assessed in accordance with quality standard for fresh fruits and vegetables SR1423/2003 - eggplants. Non

Tab.1. Effect of grafting two cultivars of eggplant on various rootstocks on their production and earliness when growing in 2 different soil temperatures

\begin{tabular}{|c|c|c|c|c|c|c|}
\hline \multirow[b]{2}{*}{ Rootstock } & \multirow[b]{2}{*}{$\begin{array}{l}\text { Cultivar } \\
\text { grafted }\end{array}$} & \multicolumn{2}{|c|}{$12^{\circ} \mathrm{C}$} & \multicolumn{2}{|c|}{$17^{\circ} \mathrm{C}$} & \multirow[b]{2}{*}{$\sum{ }^{0} \mathrm{C}$} \\
\hline & & 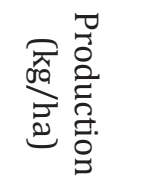 & 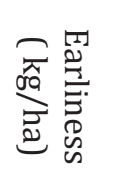 & 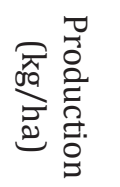 & 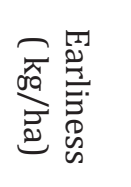 & \\
\hline \multirow{2}{*}{ King Kong } & AndraF1 & 3.84 & 0.46 & 4.80 & 1.16 & 3514 \\
\hline & SharapovaF1 & 5.45 & 0.58 & 6.81 & 1.46 & 3337 \\
\hline \multicolumn{2}{|c|}{ Average } & $4.65 \mathrm{ab}^{*}$ & $0.52 \mathrm{ab}$ & $5.81 \mathrm{ab}$ & $1.31 \mathrm{ab}$ & 3425 \\
\hline \multirow{2}{*}{ Emperador } & AndraF1 & 5.05 & 0.61 & 6.31 & 1.50 & 3514 \\
\hline & SharapovaF1 & 6.22 & 0.98 & 7.77 & 2.44 & 3337 \\
\hline \multicolumn{2}{|c|}{ Average } & $5.64 \mathrm{a}$ & $0.79 \mathrm{a}$ & $7.04 \mathrm{a}$ & $1.97 \mathrm{a}$ & 3425 \\
\hline \multirow{2}{*}{ Hikyaku } & AndraF1 & 3.90 & 0.62 & 5.57 & 1.56 & 3526 \\
\hline & SharapovaF1 & 5.12 & 0.67 & 7.32 & 1.67 & 3349 \\
\hline \multicolumn{2}{|c|}{ Average } & $4.51 \mathrm{ab}$ & $0.64 \mathrm{a}$ & $5.57 \mathrm{~b}$ & $1.62 \mathrm{a}$ & 3437 \\
\hline \multirow{2}{*}{ KA-312 } & AndraF1 & 3.76 & 0.28 & 5.38 & 0.71 & 3710 \\
\hline & SharapovaF1 & 4.37 & 0.31 & 6,24 & 0.81 & 3533 \\
\hline \multicolumn{2}{|c|}{ Average } & $4.06 \mathrm{~b}$ & $0.30 \mathrm{~b}$ & $5.81 \mathrm{ab}$ & $0.76 \mathrm{~b}$ & 3621 \\
\hline \multirow{2}{*}{ Torvum vigor } & AndraF1 & 3.26 & 0.39 & 4.67 & 0.97 & 3365 \\
\hline & SharapovaF1 & 4.40 & 0.32 & 6.29 & 0.83 & 3365 \\
\hline \multicolumn{2}{|c|}{ Average } & $3.83 \mathrm{~b}$ & $0.36 \mathrm{~b}$ & $5.48 \mathrm{~b}$ & $0.90 \mathrm{~b}$ & 3365 \\
\hline \multirow{2}{*}{ Espina } & AndraF1 & 3.39 & 0.55 & 4.84 & 1.38 & 3297 \\
\hline & SharapovaF1 & 4.42 & 0.39 & 6.31 & 0.98 & 3369 \\
\hline \multicolumn{2}{|c|}{ Average } & $3.90 \mathrm{~b}$ & $0.47 \mathrm{~b}$ & $5.58 \mathrm{~b}$ & $1.18 \mathrm{~b}$ & 3333 \\
\hline \multirow{2}{*}{$\begin{array}{l}\text { Non grafted } \\
\text { eggplants }\end{array}$} & AndraF1 & 2.75 & 0.14 & 4.04 & 1.71 & 3323 \\
\hline & SharapovaF1 & 3.18 & 0.24 & 6.26 & 1.99 & 3323 \\
\hline \multicolumn{2}{|c|}{ Average non grafted eggplants } & $2.97 \mathrm{c}$ & $0.19 \mathrm{c}$ & $5.15 \mathrm{~b}$ & $1.85 \mathrm{a}$ & 3323 \\
\hline \multicolumn{2}{|c|}{ Average grafted eggplants } & 4.43 & 0.51 & 5.88 & 1.29 & 3434.33 \\
\hline
\end{tabular}


- grafted eggplants produced 81\% fruits of Extra and First quality, while grafted eggplants produced $94.08 \%$. When planted in unfavorable environmental conditions, grafted eggplants as well as non-grafted recorded an over $12 \%$ decrease of the fruits amount of Extra and First quality.

The rootstocks which led to a special quality of fruit were in order: KA - 312 (97\%), Torvum vigor (95.5\% eggplants of Extra quality and First), Hikyaku(95\%), Emperador and Espina(92.5\%) and King Kong(92\%).

The nutritional value of eggplants expressed as soluble dry matter content and total carbohydrates have not undergone significant changes in the process of grafting.

When soil temperature was $17^{\circ} \mathrm{C}$, the soluble substance content was $5.3 \%$ for non-grafted eggplants and $5.18 \%$ for grafted eggplants. Total carbohydrates content was $2.77 \%$ for non-grafted eggplants and $2.07 \%$ for grafted plants. By planting the eggplants in a soil with temperature of $12^{\circ} \mathrm{C}$, the values of the biochemical quality indicators had a slight decrease, with values ranging between $0.35-0.83 \%$ ( soluble substance content) and 0.17 $0.23 \%$ ( total carbohydrates) .

Good nutritional qualities were conferred by Hikyaku eggplant rootstock, with a soluble dry matter content of $5.8 \%$ and total carbohydrates of

Tab.2. Effect of grafting two cultivars of eggplant on various rootstocks on their regarding commercial quality and nutritional value when growing in two different soil temperatures

\begin{tabular}{|c|c|c|c|c|c|c|c|}
\hline \multirow[b]{3}{*}{ Rootstock } & \multirow[b]{3}{*}{$\begin{array}{l}\text { Cultivar } \\
\text { grafted }\end{array}$} & \multicolumn{3}{|c|}{$12^{\circ} \mathrm{C}$} & \multicolumn{3}{|c|}{$17^{\circ} \mathrm{C}$} \\
\hline & & \multirow[b]{2}{*}{$\begin{array}{c}\text { Quality } \\
(\mathrm{E}+\mathrm{I}) \%\end{array}$} & \multicolumn{2}{|c|}{ Nutritional value } & \multirow[b]{2}{*}{$\begin{array}{l}\text { Quality** } \\
(\mathrm{E}+\mathrm{I}) \%\end{array}$} & \multicolumn{2}{|c|}{ Nutritional value } \\
\hline & & & $\begin{array}{l}\text { SDM } \\
\left({ }^{0} \mathrm{R}\right)\end{array}$ & $\begin{array}{c}\text { total } \\
\text { carbohy- } \\
\text { drates(\% }\end{array}$ & & $\operatorname{SDM}\left({ }^{\circ} \mathrm{R}\right)$ & $\begin{array}{c}\text { total } \\
\text { carbohy- } \\
\text { drates (\%) }\end{array}$ \\
\hline \multirow{2}{*}{ King Kong } & AndraF1 & 84 & 4.5 & 2.01 & 90 & 4.7 & 2.02 \\
\hline & SharapovaF1 & 89 & 4.3 & 1.32 & 94 & 4.5 & 1.43 \\
\hline \multicolumn{2}{|c|}{ Average } & $86.5 a^{*}$ & $4.4 \mathrm{a}$ & $1.66 \mathrm{a}$ & $92 \mathrm{a}$ & $4.6 \mathrm{a}$ & $1.73 \mathrm{a}$ \\
\hline \multirow{2}{*}{ Emperador } & AndraF1 & 78 & 4.6 & 1.63 & 90 & 5.1 & 1.73 \\
\hline & SharapovaF1 & 81 & 5.1 & 1.98 & 95 & 5.3 & 2.23 \\
\hline \multicolumn{2}{|c|}{ Average } & $79.5 \mathrm{a}$ & $4.85 a$ & $1.81 \mathrm{a}$ & $92.5 \mathrm{a}$ & $5.2 \mathrm{a}$ & $1.98 \mathrm{a}$ \\
\hline \multirow{2}{*}{ Hikyaku } & AndraF1 & 77 & 5.1 & 2.14 & 92 & 5.5 & 2.54 \\
\hline & SharapovaF1 & 82 & 5.8 & 2.12 & 98 & 6.1 & 2.32 \\
\hline \multicolumn{2}{|c|}{ Average } & $79.5 a$ & $5.45 a$ & $2.13 \mathrm{a}$ & $95 a$ & $5.8 \mathrm{a}$ & $2.43 a$ \\
\hline \multirow{2}{*}{ KA-312 } & AndraF1 & 81 & 5.0 & 1.98 & 96 & 5.4 & 2.01 \\
\hline & SharapovaF1 & 83 & 5.2 & 1.61 & 98 & 5.4 & 1.91 \\
\hline \multicolumn{2}{|c|}{ Average } & $82 a$ & $5.1 \mathrm{a}$ & $1.80 \mathrm{a}$ & $97 a$ & $5.4 \mathrm{a}$ & $1.96 \mathrm{a}$ \\
\hline \multirow{2}{*}{ Torvum vigor } & AndraF1 & 84 & 5.1 & 2.07 & 94 & 5.3 & 2.22 \\
\hline & SharapovaF1 & 86 & 4.3 & 2.00 & 97 & 4.9 & 2.05 \\
\hline \multicolumn{2}{|c|}{ Average } & $85 a$ & $4.7 \mathrm{a}$ & $1.79 \mathrm{a}$ & $95.5 a$ & $5.1 \mathrm{a}$ & $2.14 \mathrm{a}$ \\
\hline \multirow{2}{*}{ Espina } & AndraF1 & 78 & 4.6 & 2.51 & 91 & 4.9 & 2.66 \\
\hline & SharapovaF1 & 81 & 4.9 & 1.67 & 94 & 5.0 & 1.74 \\
\hline \multicolumn{2}{|c|}{ Average } & $79.5 \mathrm{a}$ & $4.75 a$ & $2.09 \mathrm{a}$ & $92.5 a$ & $4.95 \mathrm{a}$ & $2.2 \mathrm{a}$ \\
\hline \multirow{2}{*}{ Ungrafted eggplants } & AndraF1 & 64 & 4.6 & 2.39 & 79 & 5.3 & 2.57 \\
\hline & SharapovaF1 & 72 & 4.8 & 2.69 & 83 & 5.3 & 2.97 \\
\hline \multicolumn{2}{|c|}{ Average non-grafted plants } & $68 b$ & $4.72 \mathrm{a}$ & $2.54 \mathrm{a}$ & $81 b$ & $5.3 a$ & $2.77 \mathrm{a}$ \\
\hline \multicolumn{2}{|c|}{ Average grafted plants } & 82.00 & 4.88 & 1.92 & 94.08 & 5.18 & 2.07 \\
\hline
\end{tabular}


$2.43 \%$. In the case of the experimental plot from the unheated greenhouses of Horting Institute - where soil has not been disinfected from 2005 - the experimental plots were labeled based on the obtained results, depending on the level of soil infestation with pathogens Verticillium dahlia, respectively Fusarium oxysporum $f$. $s p$. melongenae, in second class (medium infestation), and depending on the level of infestation of the soil with Meloidogyne spp., in third class (high infestation).

In the circumstances of a natural level of soil infection with Verticillium dahlia and Fusarium oxysporum f.sp. melongenae, the eggplants grafting resulted in a pronounced reduction in the frequency of symptoms on plants and a consistent decrease of the attack intensity and attack degree: disease incidence (I \%), disease severity (S \%) and attack degree (AD \%) (Tab. 3).

The obtained results showed a high degree of tolerance of the grafted eggplants. Thus, the frequency of plants attacked by Verticillium dahlia was $4.3-7.5 \%$ in the case of non-grafted eggplants and $0.12 \%$ for grafted plants. The degree of attack was between $0.00 \%$ for grafted plants up to and $0.58 \%$ for non-grafted eggplants.

Similar results were recorded in the case of pathogen Fusarium oxysporum $f$ agent. $s p$. melongena. The disease incidence was in the range 2.4\% Sharapova F1 and 4.15\% Andra F1. For grafted eggplants the disease incidence was of $0,00 \%$. The disease severity was $5.3-8.9 \%$ for non-grafted eggplants and $0.00 \%$ for grafted eggplants. Also, the attack degree was $0.00 \%$ for

Tab. 3. Effect of grafting two cultivars of eggplant on various rootstocks and various soil pathogens, on a soil with a medium natural level of infection, when growing in two different soil temperatures.

\begin{tabular}{|c|c|c|c|c|c|c|c|}
\hline \multirow{2}{*}{ Rootstock } & \multirow{2}{*}{$\begin{array}{l}\text { Cultivar } \\
\text { grafted }\end{array}$} & \multicolumn{3}{|c|}{$\begin{array}{l}\text { Verticillium dahlia } \\
\qquad(\%)\end{array}$} & \multicolumn{3}{|c|}{$\begin{array}{c}\text { Fusarium oxysporum } \mathrm{f} \text {. } \\
\text { sp. melongenea } \\
(\%)\end{array}$} \\
\hline & & $\mathrm{I}^{* *}$ & $\mathrm{~S}$ & $\mathrm{AD}$ & $\mathrm{I}$ & $\mathrm{S}$ & $\mathrm{AD}$ \\
\hline \multirow{2}{*}{ King Kong } & AndraF1 & 0 & 0 & 0 & 0 & 0 & 0 \\
\hline & SharapovaF1 & 0 & 0 & 0 & 0 & 0 & 0 \\
\hline \multicolumn{2}{|c|}{ Average } & $0 \mathrm{a}$ & 0 & 0 & $0 \mathrm{a}$ & 0 & 0 \\
\hline \multirow{2}{*}{ Emperador } & AndraF1 & 0 & 0 & 0 & 0 & 0 & 0 \\
\hline & SharapovaF1 & 0 & 0 & 0 & 0 & 0 & 0 \\
\hline \multicolumn{2}{|c|}{ Average } & $0 \mathrm{a}$ & 0 & 0 & $0 \mathrm{a}$ & 0 & 0 \\
\hline \multirow{2}{*}{ Hikyaku } & AndraF1 & 0 & 0 & 0 & 0 & 0 & 0 \\
\hline & SharapovaF1 & 0 & 0 & 0 & 0 & 0 & 0 \\
\hline \multicolumn{2}{|c|}{ Average } & $0 \mathrm{a}$ & 0 & 0 & $0 \mathrm{a}$ & 0 & 0 \\
\hline \multirow{2}{*}{ KA-312 } & AndraF1 & 0,7 & 1.1 & 0.00 & 0 & 0 & 0 \\
\hline & SharapovaF1 & 0 & 0 & 0 & 0 & 0 & 0 \\
\hline \multicolumn{2}{|c|}{ Average } & $0.35 a$ & 0.55 & 0 & $0 \mathrm{a}$ & 0 & 0 \\
\hline \multirow{2}{*}{ Torvum vigor } & AndraF1 & 0 & 0 & 0 & 0 & 0 & 0 \\
\hline & SharapovaF1 & 0 & 0 & 0 & 0 & 0 & 0 \\
\hline \multicolumn{2}{|c|}{ Average } & $0 \mathrm{a}$ & 0 & 0 & $0 \mathrm{a}$ & 0 & 0 \\
\hline \multirow{2}{*}{ Espina } & AndraF1 & 0.7 & 1.1 & 0 & 0 & 0 & 0 \\
\hline & SharapovaF1 & 0 & 0 & 0 & 0 & 0 & 0 \\
\hline \multicolumn{2}{|c|}{ Average } & $0.35 a$ & 0.55 & 0 & $0 \mathrm{a}$ & 0 & 0 \\
\hline \multirow{2}{*}{$\begin{array}{l}\text { Ungrafted } \\
\text { eggplants }\end{array}$} & AndraF1 & 7.5 & 11.3 & 0.84 & 5.9 & 8.9 & 0.52 \\
\hline & SharapovaF1 & 4.3 & 7.4 & 0.32 & 2.4 & 5.3 & 0.12 \\
\hline \multicolumn{2}{|c|}{ Average non-grafted eggplants } & $5.9 \mathrm{~b}$ & 9.35 & 0.58 & $4.15 \mathrm{~b}$ & 7.10 & 0.32 \\
\hline \multicolumn{2}{|c|}{ Average grafted eggplants } & 0.12 & 0.18 & 0.00 & 0.00 & 0.00 & 0.00 \\
\hline
\end{tabular}


grafted eggplants and $0.32 \%$ for non-grafted plants.

The results regarding the presence and severity of galls produced by nematodes attack on the roots of the eggplants, determined and recorded at the end of the production cycle and clearing the eggplant culture are shown in Tab. 4.

Grafting eggplants led to a significant reduction in attack frequency produced by Meloidogyne spp. on plant's roots. While in the case of non-grafted eggplants there was an disease incidence pest of $18.85 \%$, when plants were grafted the frequency of nematode attack had not exceeded the value of $2.11 \%$. Besides, the variation range recorded for all combinations (rootstock $\mathrm{x}$ scion) was quite tight: from $0.9 \%$ (Emperador $\mathrm{x}$ Sharapova) to $4.0 \%$ (Espina $\mathrm{x}$ AndraF1). The data regarding the severity of nematodes attack on the eggplants roots eggplants, roots expressed by the index, determined by Di Vito and Lamberti (1971), the grading scale(0-5) whose value expresses the number of galls from the roots, their spread and size, showed a high tolerance of the grafted plants to nematodes attack. Practically, in the case of grafted plants, the nematodes galls index on the roots of eggplants was between 0.8(Emperador $\mathrm{x}$ Sharapova) and 2.3(Espina $\mathrm{x}$ AndraF1) representing a level of infestation very weak to weak, with a number of galls between 3 and 8, isolated spread on root system and respectively 2.9(AndraF1) on non-grafted plants, representing a medium level of infestation to strong, with over 20 galls with spread throughout all the root system, including main roots. The obtained results are consistent with those presented by Oda, 1993

Tab. 4. Effect of grafting two cultivars of eggplant on various rootstocks and various soil pathogens, against nematode attack on a soil with high degree of natural infection, when growing in two different soil temperatures

\begin{tabular}{|c|c|c|c|}
\hline Rootstock & $\begin{array}{c}\text { Cultivar } \\
\text { grafted }\end{array}$ & $\begin{array}{c}\text { Disease incidence } \\
\text { (\% attacked plants) }\end{array}$ & $\begin{array}{c}\text { Galls on roots } \\
\text { (index } 0-5 \text { ) }\end{array}$ \\
\hline \multirow{2}{*}{ King Kong } & AndraF1 & 2.1 & 1.4 \\
\hline & SharapovaF1 & 1.3 & 1.1 \\
\hline \multirow{3}{*}{ Emperador } & Average & $1.7 \mathrm{a}$ & $1.25 \mathrm{a}$ \\
\hline & AndraF1 & 1.9 & 1.4 \\
\hline & SharapovaF1 & 0.9 & 0.8 \\
\hline & Average & $1.4 \mathrm{a}$ & $1.1 \mathrm{a}$ \\
\hline \multirow{2}{*}{ Hikyaku } & AndraF1 & 2.4 & 1.3 \\
\hline & SharapovaF1 & 1.4 & 1.1 \\
\hline & Average & $1.9 \mathrm{a}$ & $1.2 \mathrm{a}$ \\
\hline \multirow{2}{*}{ KA-312 } & AndraF1 & 3.1 & 2.1 \\
\hline & SharapovaF1 & 2.9 & 1.9 \\
\hline & Average & $3.0 \mathrm{a}$ & $2.0 \mathrm{ab}$ \\
\hline \multirow{2}{*}{ Torvum vigor } & AndraF1 & 2.2 & 1.6 \\
\hline & SharapovaF1 & 1.4 & 1.3 \\
\hline & Average & $1.8 \mathrm{a}$ & $1.45 \mathrm{a}$ \\
\hline \multirow{2}{*}{ Espina } & AndraF1 & 4.0 & 2.3 \\
\hline & SharapovaF1 & 1.7 & 1.7 \\
\hline \multirow{3}{*}{$\begin{array}{l}\text { Ungrafted } \\
\text { eggplants }\end{array}$} & Average & $2.85 a$ & $2.0 \mathrm{ab}$ \\
\hline & AndraF1 & 24.3 & 2.9 \\
\hline & SharapovaF1 & 13.4 & 1.4 \\
\hline \multicolumn{2}{|c|}{ Average non grafted eggplants } & $18.85 \mathrm{~b}$ & $2.15 \mathrm{~b}$ \\
\hline \multicolumn{2}{|c|}{ Average grafted eggplants } & 2.11 & 1.50 \\
\hline
\end{tabular}

*In each column, the mean values noted with the same letter do not present significant difference after the Duncan test, for $\mathrm{p}=5 \%$ 
Tab. 5. Elements of economic effectiveness regarding eggplants culture(grafted plants vs. non-grafted plants)*

\begin{tabular}{|c|c|c|c|c|c|c|c|}
\hline \multirow[t]{2}{*}{ Culture type } & \multirow{2}{*}{$\begin{array}{c}\text { Average } \\
\text { production } \\
\text { (t/ha) }\end{array}$} & \multirow{2}{*}{$\begin{array}{l}\text { Quality } \\
\text { E+ I } \\
(\%)\end{array}$} & \multirow{2}{*}{$\begin{array}{l}\text { Average } \\
\text { price } \\
(\text { Euro/t) }\end{array}$} & \multirow{2}{*}{$\begin{array}{l}\text { Incomes } \\
\text { (Euro**) }^{* *}\end{array}$} & \multirow{2}{*}{$\begin{array}{l}\text { Total } \\
\text { expenses } \\
\text { (Euro) } \\
\end{array}$} & \multicolumn{2}{|c|}{$\begin{array}{c}\text { Financial results } \\
\text { (Euro) }\end{array}$} \\
\hline & & & & & & + & - \\
\hline $\begin{array}{l}\text { Non-grafted } \\
\text { eggplants }\end{array}$ & 98.8 & 73 & 84.93 & 8391.9 & 3827.16 & 4564.74 & - \\
\hline $\begin{array}{c}\text { Grafted } \\
\text { eggplants }\end{array}$ & 122.4 & 88 & 93.08 & 11393.77 & 4716.05 & 6677.72 & - \\
\hline
\end{tabular}

and confirm the tolerance effect of grafted plants against nematodes (Meloidogyne sp.)

In order to determine the effectiveness of using the method of grafting eggplants some elements of economic effectiveness were analyzed. According to the data presented(Tab. 5), the use of grafted plants increases profits.

Average production/ha in the case of nongrafted eggplants - based on the obtained results - can reach 98.8 tone/ha, while a grafted eggplant crop could achieve a production of 122.4 tone/ha; also, in terms of commercial quality, there was an average of Extra quality and First quality fruits in the case of non-grafted eggplants of $73 \%$ and $88 \%$ in the case of grafted plants. Considering an average price of 84.93 Euro for non-grafted plants and 93.08 Euro for grafted eggplants (due to the superior quality with over 15\%), the potential revenues are 8391.9 Euro in the case of a hectare of non-grafted eggplants crop and, respectively 11393.77 Euro in case of a hectare of grafted eggplants.

Total expenses (seeds and seedlings, pesticides, fertilizers, auxiliary materials, labor, water, energy, etc.) represent 3827.16 Euro for a non-grafted culture and 4716.05 Euro for grafted eggplants (there are additional costs for obtaining the seedlings). The estimated financial results are positive and could be worth 4564.74 Euro for non-grafted eggplants and with $46.29 \%$ higher, respectively 6677.72 Euro, for grafted eggplants.

The better results recorded at the eggplants grafted (referring to marketable yield, quality, etc.) seems to be mainly due to the root system of the plants. It is known as the root system of the plants affects the vegetative growth and yield. As a result it is obvious that the differences in the root system of the grafted and non-grafted plants, leads to the efficiency water and nutrient uptake of by the roots.

The differences in quality, yield and earliness could be attributed to the different growth characteristics of the cultivars and to their different affinity to grafting and compatibility with the rootstock. Thus, (Suzuki \& Morishita, 2002; Sebahattin et al.,2009 ) showed that Solanum torvum is a vigorous rootstock, and a graft combination of a vigorous cultivar with an equally vigorous rootstock reduces the amount of fertilizer required for the same yield. Earliness could also be associated with the high vigour of the rootstock. Gisbert et al. (2011) have mentioned that the earliness was observed mainly in the interspecific hybrids, respective between S. melongena and S. aethiopicum or S. incanum.

\section{CONCLUSIONS}

The obtained results highlight the positive effect of grafting eggplants on the average production. The best results were recorded in the grafting where has been used the rootstock Emperador, Hikyaku and King Kong. In the circumstances of a natural medium level of soil infection with Verticillium dahlia and Fusarium oxysporum f.sp. melongenae, eggplants grafting led to a significant decrease of the frequency of symptoms on plants and a consistent reduction of the disease incidence, disease severity and attack degree. Eggplants grafting led to a significant reduction of the frequency of Meloidogyne sp. attack on eggplants roots. Using grafted plants increased the final profit.

\section{REFERENCES}

1. Assenza M (2004). Grafting tomatoes, an alternative to methyl bromide. InformatoreAgrario 60, 46,41-43. 
2. Bausher MG, Chellemi DO (2010). Performance of Grafted Tomatoes in Open Field Trials at Two Locations in Florida. Annual International Research Conference on Methyl Bromide Alternatives and Emissions Reduction, 77-1:772.

3. Bletsos F, Thanassoulopoulos C, Roupakias D (2003) Effect of grafting on growth, yield andVerticillium wilt of eggplant. HortScience 38:183-186.

4. Bogoescu M, Gullino ML, Minuto A , Amadio A (2007). Alternatives to methyl bromide in Romanian protected crops. Acta Horticulturae (ISHS) 698:315-320.

5. Di Vito M , Lamberti F (1971). La resistenza del pomodoro nei confronti dei nematodi galligeni: prospettive e possibilità. Rivista di Agronomia, 13: 313 - 322.

6. Edelstein M, Ben-Hur M (2015). Grafting: a useful tool to increase tolerance to toxic elements in vegetables under arid and semiarid conditions. Acta Horticulturae (ISHS) 1086:133-140

7. Gisbert C, Prohens J, Nuez F (2011). Eggplant relatives as sources of variation for developing new rootstocks: Effects of grafting on eggplant yiel d and fruit apparent quality and composition. Sci. Hort. 128, 14-22.

8. Gullino ML, Camponogara A, Gasparrini G, Clini C Garibaldi A (2003). Replacing methyl bromide for soil disinfestations: The Italian experience and the implication for other countries.Plant Disease 87:1012-1021.

9. Khah EM (2011). Effect of grafting on growth, performance and yield of aubergine (Solanum melongena L.) in greenhouse and open-field. International Journal of Plant Production. 5(4): 359-366.

10. Oda M (1993). Present state of vegetable production using grafted plants in Japan. Agr. Hort.68:442-446.

11. Romano D , Paratore A(2001). Effects of grafting on tomato and eggplant. Acta Hortic. 559, 149-154; DOI: 10.17660/ ActaHortic.2001.559.21 ; http://dx.doi.org/10.17660/ ActaHortic.2001.559.21

12. Sebahattin Ç, Yıldız D, Sedat M, Şener K, Meltem M, Özgür A, Gülcan T (2009). Grafted eggplant yield, quality and growth in infested soil with Verticillium dahliae and Meloidogyne incognita. Pesq. agropec. bras. vol.44 no.12 Brasília, http://dx.doi.org/10.1590/S0100-204X200900 1200017.

13. Suzuki T, Morishita M (2002). Effects of scion and rootstock cultivars on growth and yield of eggplant cultured under two fertilizer levels. Journal of the Japanese Society for Horticultural Science, v.71, p.568-574, 2002. 